\title{
Supply estimate and projection for poultry meat in Pakistan by the year 2030 AD
}

\author{
Khalid Mahmood Aujla ${ }^{1}$ and Nadeem Sadiq ${ }^{2 *}$ \\ 1. Pakistan Agricultural Research Council, Islamabad-Pakistan \\ 2. Balochistan Agricultural Research \& Development Center, Quetta-Pakistan \\ *Corresponding author's email: nadeemqta@yahoo.com \\ Citation \\ Khalid Mahmood Aujla and Nadeem Sadiq. Supply estimate and projection for poultry meat in Pakistan by the \\ year 2030 AD. Pure and Applied Biology. Vol. 7, Issue 2, pp460-465. \\ http://dx.doi.org/10.19045/bspab.2018.70057
}

\begin{tabular}{llll}
\hline \hline Received: 09/01/2018 & Revised: 26/03/2018 & Accepted: 29/03/2018 & Online First: 06/04/2018 \\
\hline \hline
\end{tabular}

\section{Abstract}

Poultry sub-sector is an important and vibrant segment of Agriculture in Pakistan. Poultry meat supply in Pakistan by the year 2030 AD has been projected based on the time series data from 1980-81 to 2011-12. This study has been planned to estimate the poultry meat need in Pakistan in the next decade by 2030. Impact of important factors on poultry meat production have been studied by employing linear regression and polynomial price lag models. The poultry meat production has grown at high rate during last few years and actual prices have decreased, thus effect of poultry meat prices on its supply is found insignificant. Poultry population contributes positively and significantly to poultry meat production in the country. The coefficient of poultry feed prices has the negative sign but was statistically insignificant, indicating that poultry birds are good converters of feed into products of highly nutritive value. Availability of agricultural credit has not affected poultry meat production significantly in the country. Similarly, overtime insignificant change in poultry production technology has been observed. Though, in recent past increase in controlled house broiler farming has spurred the poultry meat production in the country. Poultry meat supply is projected to be 3289 and 3319 thousand tonnes under specifications of linear and polynomial price lag models, respectively. It is hoped that poultry meat production will grow at about 8.0 percent per annum by the year 2030, against past growth rate of 9.1 percent per annum during 1980-81 to 2011-12. Thus, policy interventions would be required in the long run to boost poultry meat production in the country. Keywords: Pakistan; Poultry meat; Prices; Projections; Supply \section{Introduction}

Poultry is a vibrant sub-sector of livestock and act as a check and balance force for stabilizing the prices of meat in the country. After textiles, poultry is the second largest industry of Pakistan [1]. Poultry sub-sector contributed 10.8 percent to livestock value added. The contribution of the sub-sector to agriculture value added was 6.1 percent. Total poultry meat production in the year 2012-13 was 907 thousand tonnes with a share in the national meat production of 25.8 percent. Poultry sector has a high inherent growth potential and has grown at a rate of 8-10 percent per annum. High growth in the sub-sector is envisaged by improving regulatory framework, disease control and genetic improvement in rural poultry; hi-tech production under environmentally-controlled housing; processing and value addition; improving bio-security; need based research \& 
development and farmers' training \& education [2]. Presently number of environmental control houses for poultry meat production in the country are 2500 , out of which 75 percent (1875) are in Punjab and reaming 25 percent (625) are in other provinces [3]. Though, potential of poultry industry is growing and variety of end products is also increasing rapidly; however, the industry is facing various problems viz. energy crisis, distress sales during disasters, diseases and lack of supporting policy etc. [1]. Moreover, small poultry farms could not sustain pressure from controlled house corporate farms. Fifty percent of the small farms have already been swallowed by controlled house corporate farms during last six years. This has resulted into job loss for around 25 percent of the manpower engaged in the industry [4].

Overtime, share of poultry meat has surpassed the share of mutton in the national meat production and it has appeared as a substitute for mutton in the diets of the people. Poultry meat is easily available in all parts of the country and is also afforded by low income strata of the society [5]. Poultry in the country is produced under two management systems i.e. domestic and commercial. However, commercial poultry farming completely dominates the domestic poultry in production of poultry meat. Poultry meat and eggs production take shorter time than other types of meat (beef and mutton). These are superior sources of protein, essential amino acids, mineral and vitamins [6]. Moreover, poultry meat contains low fats than other types of meat and thus prevents hardening of arteries [7]. In short, poultry production is considered most economical and efficient system of producing essential food.

Poultry meat supply projections are central for effective policy formulation for the growth and development of the poultry industry. In this perspective, few researchers have analyzed supply of meat /poultry meat in Pakistan viz. [8] and [9].
Study by Ahmad and Chaudhary was based on simple growth model; however, [9] used polynomial price lag model to estimate supply response function of poultry meat in the country. This study has been carried out to make supply projection of poultry meat by the year 2030. Moreover, impacts of various factors on the supply of poultry meat in the country have also been analyzed.

\section{Materials and methods}

Supply side analysis of poultry meat is based on time series data for the time period 1980-81 to 2011-12 about production, prices, poultry population, feed prices, amount of agricultural credit disbursed by Zari Taraqiati Bank Limited (ZTBL) and the stage of production technology. Prices as well as other monetary variables are converted at the prices of year 2000-01. Moreover, the projection of supply (production) requires knowledge of future values of exogenous variables. These variables are projected using their growth trends over the last thirty-two years (198081 to 2011-12). Poultry population in the year 2011-12 was 785 million, with per bird meat production of $1.2 \mathrm{~kg}$. It is projected that poultry population would be 2779 million by the year 2030 with an annual growth rate of 7.3 percent. Over the last thirty-two years (1980-81 to 2011-12) growth rates in nominal and real poultry meat prices were 7.4 and -1.7 percent, respectively. Thus, these growth rates in prices have been used for making poultry meat supply projections. The linear regression and polynomial price lag models used for the study are given by equations 1 and 2, respectively:

$\log \mathrm{PS}_{\mathrm{t}}=\mathrm{B}_{\mathrm{o}}+\mathrm{B}_{1} \log \mathrm{PC}_{\mathrm{t}}+\mathrm{B}_{2} \log \mathrm{P} \mathrm{P}+$ $\mathrm{B}_{3} \log \mathrm{PF}+\mathrm{B}_{4} \log \mathrm{AC}+\mathrm{T}+\mathrm{u}_{\mathrm{t}} \quad(1)$

$\log \mathrm{PS}_{\mathrm{t}}=\mathrm{B}_{\mathrm{o}}+\mathrm{B}_{1} \log \mathrm{PC}_{\mathrm{t}}+\mathrm{B}_{2} \log \mathrm{PC}_{\mathrm{t}-1}+$ $\mathrm{B}_{3} \log \mathrm{PC}_{\mathrm{t}-2}+\mathrm{B}_{4} \log \mathrm{PP}+\mathrm{B}_{5} \log \mathrm{PF}$

$+\mathrm{B}_{6} \log \mathrm{AC}+\mathrm{T}+\mathrm{u}_{\mathrm{t}}(2)$

Where PSt is quantity of poultry meat production (Thousand Tonnes)

$\mathrm{PC}_{\mathrm{t}}$ is poultry meat price of current period (Rs./kg)

$\mathrm{PC}_{\mathrm{t}-1}$ is one lag poultry meat price (Rs./kg) 
$\mathrm{PC}_{\mathrm{t}-2}$ is two lag poultry meat price (Rs./kg)

$\mathrm{PP}$ is the poultry population (Million Number)

PF is poultry feed price (Rs. $/ 50 \mathrm{~kg}$ bag)

$\mathrm{AC}$ is amount of agricultural credit disbursed by ZTBL (Rs./annum)

$\mathrm{T}$ is the time, which is a proxy for technological change and

$\beta i$ 's are the coefficient of the variables.

$\mu_{t}$ is error term, which may arise due to aggregate effect of variables not included in the model.

The supply projections for the poultry meat have been made through following expression (equation 3):

$\mathrm{PS}_{\mathrm{t}}=\mathrm{PS}_{0} * \mathrm{~N}_{\mathrm{t}}\left(1+\mathrm{PC}_{\mathrm{g}} * \mathrm{PE}_{\mathrm{s}}\right)(3)$

Where, $P S_{t}$ is supply/ production of poultry meat in year $t$

$\mathrm{PS}_{0}$ is the poultry meat production per bird unit in the base year (2011-12),
$\mathrm{PC}_{\mathrm{g}}$ is growth in nominal prices,

$\mathrm{PE}_{\mathrm{s}}$ is price elasticity of supply for poultry meat;

$\mathrm{N}_{\mathrm{t}}$ is projected poultry population in year $\mathrm{t}$.

\section{Results and discussion}

Unit Root Test (Augmented Dickey-

\section{Fuller Test: ADF)}

The results of unit root test are given in Table 1. Variables of poultry meat supply (PS) and poultry population (PP) are stationary at first difference with both intercept and trend terms. Variable of poultry meat price (PC) is stationary at level without both intercept and trend terms. The variable of poultry feed price (FP) is also stationary at level but along with intercept term. The variable of agricultural credit disbursed by ZTBL (AC) is non stationary at level along with intercept, but become stationary at first difference.

Table 1. Unit Root Test (Augmented Dickey-Fuller Test: ADF)

\begin{tabular}{|c|c|c|c|c|}
\hline Variables & $\begin{array}{c}\text { Intercept / Intercept } \\
\text { and Trend }\end{array}$ & Level & Ist-difference & $\begin{array}{c}\text { Order of } \\
\text { Integration }\end{array}$ \\
\hline PS & Intercept and Trend & -0.285 & $-4.841^{* * *}$ & I $(1)$ \\
\hline PC & None & $-3.380^{* * *}$ & - & I $(0)$ \\
\hline PP & Intercept and Trend & -1.155 & $-3.933^{* *}$ & I $(1)$ \\
\hline FP & Intercept & $-3.008^{* *}$ & - & I $(0)$ \\
\hline AC & Intercept & -2.204 & $-4.577 * * *$ & I $(1)$ \\
\hline
\end{tabular}

Note: $* * *$ and $* *$ indicate the rejection of null hypothesis of unit-root at $1 \%$ and $5 \%$ levels of significance respectively

The estimated coefficients of linear regression model are presented in the (Table 2). The coefficient of poultry meat price is negative and statistically insignificant, which means that poultry meat production in the country has grown at a high rate during last few years due to rapid adoption of controlled house broiler farming and the real prices have decreased. Moreover, market behviour for poultry meat supply is unpredictable, usually gluts are followed by shortages with wider variation in prices. Poultry feed has expected negative sign i.e. an increase in feed prices results into a decrease in poultry production. However, the coefficient of poultry feed was statistically insignificant, which means that poultry birds are good converters of feed into products of highly nutritive value. The coefficient of poultry population has a positive sign and is statistically significant, indicating that poultry population contributes to poultry meat production in the country. The coefficient of Agricultural Credit disbursed by Zari Taraqiati Bank Limited (ZTBL) has a negative coefficient but is statistically insignificant. Similarly, time variable has a negative sign and was statistically insignificant. Which imply that noteworthy change in poultry production has not occurred over time. Though, in last few years a great technological advancement has occurred in poultry production through controlled house broiler farming. 
Table 2. Estimates of poultry meat supply response model (Linear regression)

\begin{tabular}{|c|c|c|c|c|}
\hline Variables & Coefficient & Std. Error & t-Statistic & Prob. \\
\hline Constant & 1.148 & 1.718 & 0.668 & 0.510 \\
\hline Poultry Meat Price & -0.184 & 0.400 & -0.461 & 0.649 \\
\hline Feed Price & -0.087 & 0.256 & -0.339 & 0.737 \\
\hline Poultry Population*** & 0.736 & 0.191 & 3.858 & 0.001 \\
\hline Agricultural Credit & -0.076 & 0.226 & -0.335 & 0.741 \\
\hline Time & -0.006 & 0.007 & -0.776 & 0.445 \\
\hline $\mathrm{R}^{2}$ & 0.436 & Mean dependent var & 0.090 \\
\hline Adjusted R & 0.324 & S.D. dependent var & 0.125 \\
\hline S.E. of regression & 0.103 & Akaike info criterion & -1.539 \\
\hline Sum squared resid & 0.264 & Schwarz criterion & -1.261 \\
\hline Log likelihood & 29.855 & \multicolumn{2}{|c|}{ F-statistic } & 3.872 \\
\hline Durbin-Watson stat & 2.334 & Prob (F-statistic) & 0.010 \\
\hline
\end{tabular}

Note: $* * *$ is significant at 1 percent level

Estimates of polynomial price lag model are given in Table 3. Coefficients of poultry meat price of the current period and with two lag values have negative signs. While, the coefficient of poultry meat price with one lag value has a positive sign. However, all the coefficients of poultry meat price in the polynomial price lag model are found statistically insignificant. According to results of polynomial price lag model, increase in poultry population would improve poultry meat supply in the country. All other variables of the polynomial price lag model have similar interpretations as given in the linear regression model.

Table 3. Estimates of poultry meat supply response model (Polynomial price lag model)

\begin{tabular}{|c|c|c|c|c|}
\hline Variables & Coefficient & Std. Error & t-Statistic & Prob. \\
\hline Constant & 0.653 & 2.366 & 0.276 & 0.785 \\
\hline Poultry Meat Price & -0.224 & 0.484 & -0.464 & 0.647 \\
\hline Poultry Meat Price t- 1 & 0.171 & 0.429 & 0.400 & 0.693 \\
\hline Poultry Meat Price t-2 & -0.012 & 0.497 & -0.023 & 0.982 \\
\hline Feed Price & -0.062 & 0.276 & -0.224 & 0.825 \\
\hline Poultry Population*** & 0.722 & 0.214 & 3.380 & 0.003 \\
\hline Agricultural Credit & -0.067 & 0.246 & -0.275 & 0.786 \\
\hline Time** & -0.004 & 0.012 & -0.0312 & 0.758 \\
\hline $\mathrm{R}^{2}$ & 0.443 & \multicolumn{2}{|c|}{ Mean dependent var } & 0.089 \\
\hline Adjusted $\mathrm{R}^{2}$ & 0.266 & \multicolumn{2}{|c|}{ S.D. dependent var } & 0.127 \\
\hline S.E. of regression & 0.109 & \multicolumn{2}{|c|}{ Akaike info criterion } & -1.372 \\
\hline Sum squared resid & 0.261 & \multicolumn{2}{|c|}{ Schwarz criterion } & -0.998 \\
\hline Log likelihood & 28.573 & \multicolumn{2}{|c|}{ F-statistic } & 2.498 \\
\hline Durbin-Watson stat & 2.284 & \multicolumn{2}{|c|}{ Prob (F-statistic) } & 0.047 \\
\hline
\end{tabular}

Note: $* * * * *$ and $*$ are significant at 1,5 and 10 percent levels, respectively

The price elasticity of poultry meat obtained through linear regression is -0.184 and obtained through polynomial price lag model is -0.065 . The production of poultry meat in the year 2011-12 was 834 thousand tonnes. These findings corroborate with the findings [10] who also predicted a substantial increase in commercial poultry feed by the year 2025using regression model analysis. That will directly affect the price hike in poultry meat. Supply projections for the year 2030 with both 
linear and polynomial price lag models are 3289 and 3319 thousand tonnes, respectively. The poultry meat production is expected to grow at annual compound rate of about 8.0 percent. Growth rate in poultry meat production in Pakistan was 9.1 percent per annum from 1980-81 to 201112. Similarly, in another study [11], a significant increase in poultry meat production (40868000 to 642211000 tonnes meat) has also been predicted from 2011-2020. Thus, keeping in view past growths in poultry meat production, projections made for the year 2030 are very reasonable. High growth rate in chicken production is also supported by rapid adoption of controlled house broiler farming in the country.

\section{Conclusions and recommendations}

Overtime, share of poultry meat has surpassed the contribution of mutton in national meat production and it has appeared as a substitute of mutton in the diets of the people. Presently, poultry contributes about one-fourth in meat supply in Pakistan. Poultry birds are good converters of feed into products of highly nutritive value in shorter time than both small and large ruminants. Though, insignificant change in poultry production technology has been observed overtime; however, rapid adoption of controlled house broiler farms in last few years has spurred the production of poultry meat in the country. Rapid adoption of controlled house broiler farms has posed serious survival challenges for open house farms, thus also discouraged new investments by the small farmers in the sector. It is hoped that production of poultry meat will grow at a bit slow rate in future than phenomenal past growth rate. Thus, policy interventions would be required in the long run to boost poultry meat production in the country. These may include, support to the farmers to convert open house farms into controlled house farms through improved access to institutional credit and production inputs.

\section{Authors' contributions}

Conceived and designed the experiments: KM Aujla, Performed the experiments: KM Aujla, Analyzed the data: N Sadiq, Contributed reagents/ materials/ analysis tools: KM Aujla \& N Sadiq, Wrote the paper: KM Aujla \& N Sadiq.

\section{References}

1. Mukhtar N, Khan SH and Khan RNA (2012). Structural profile and emerging constraints of developing poultry meat industry in Pakistan. World Poultry Sci J 68(4): 749-457.

2. GOP (2014). Pakistan Economic Survey 2013-14. Economic Advisor's Wing, Finance Division, Govt of Pakistan, Islamabad.

3. NBP (2013). Poultry farming controlled environment. Agriculture Feasibility Reports. R \& D and Training Wing. Agriculture Finance Group, National Bank of Pakistan Head office, Lahore. (Available on line at http://www.nbp.com.pk/Agriculture/)

4. Anwar S (2014). Corporate farming eating up small poultry farms. September 05, 2014. The Express Tribune.

5. Mahmood T and Ayub RM (2014). An empirical study of some livestock industries of Pakistan. Sci Int 26(3): 1215-1220.

6. Mohsin AQ, Riaz R, Asad S and Mushtaq A (2008). Profitability analysis of broiler production in Rawalpindi district. Pak J Agri Sci 45(4): 514-519.

7. Alam SM and Sheikh AH (2007). Extending poultry farming in rural areas. Economics and Business Review. September 03, 2007. Daily Dawn, Pakistan.

8. Ahmad M and Chaudhry MA (1993). Demand and supply projections for major livestock products for the year 
2000 and new policy options. Pak J Agric Sci 30(2): 139-144.

9. Akmal M (1994). The production and consumption of livestock food in Pakistan: A look into the Future. Pak Dev Review 33(1): 19-39.

10. Hameed T, Zahid M, Assadullah, Muhammad KT, Asmat TM (2016). The Past, Present and Future of commercial Poultry Feed Production and Price Inclinations in Pakistan. Jokull 66(6): 61-75.

11. Hameed T, Asmat TM, Tariq MM, Bajwa MA, Rafeeq M, Hilal B, Attique MA, Bokhari FA (2017). Study on current status and future trends of commercial poultry production in Pakistan. Pure and App Biol 6(1): 190196. 